\title{
Enhanced antibiotic activity of ampicillin conjugated to gold nanoparticles on PEGylated rosette nanotubes
}

This article was published in the following Dove Press journal: International Journal of Nanomedicine

Yiwen Fan'

Alexander $C$ Pauer (D)

Arthur A Gonzales (D)

Hicham Fenniri ${ }^{1-3}$

'Department of Chemical Engineering, Northeastern University, Boston, MA 02II5, USA; ${ }^{2}$ Department of Bioengineering, Northeastern University, Boston, MA 02I I5, USA; ${ }^{3}$ Department of Chemistry and Chemical Biology, Northeastern University, Boston, MA 02115 , USA
Correspondence: Hicham Fenniri Department of Chemical Engineering, Northeastern University, 360 Huntington Avenue, Boston, MA 02115, USA

Tel + I 6173737690

Fax+l6173732209

Email h.fenniri@northeastern.edu
Purpose: This work presents the preparation of a nanocomposite of ampicillin-conjugated gold nanoparticles (AuNPs) and self-assembled rosette nanotubes (RNTs), and evaluates its antibacterial properties against two strains of drug-resistant bacteria (Staphylococcus aureus [S. aureus], methicillin-resistant $S$. aureus [MRSA]).

Materials and methods: Small, nearly monodisperse AuNPs ( $1.43 \pm 0.5 \mathrm{~nm}$ in diameter) nucleated on the surface of polyethylene glycol-functionalized RNTs in a one-pot reaction. Upon conjugation with ampicillin, their diameter increased to $1.86 \pm 0.32 \mathrm{~nm}$. The antibacterial activity of the nanocomposite against $S$. aureus and MRSA was tested using different concentrations of ampicillin. The cytocompatibility of the nanocomposite was also tested against human dermal fibroblasts.

Results: Based on bacterial inhibition studies, the nanocomposite demonstrated enhanced antibiotic activity against both bacterial strains. The minimum inhibitory concentration (MIC) of the nanocomposite against $S$. aureus was found to be $0.58 \mu \mathrm{g} / \mathrm{mL}$, which was $18 \%$ lower than ampicillin alone. The nanocomposite also exhibited a $20 \mathrm{hrs}$ MIC of $4 \mu \mathrm{g} /$ $\mathrm{mL}$ against MRSA, approximately 10-20 times lower than previously reported values for ampicillin alone. In addition, at concentrations of $4 \mu \mathrm{g} / \mathrm{mL}$ of ampicillin $(70 \mu \mathrm{g} / \mathrm{mL}$ of AuNPs), the nanocomposite showed negligible cytotoxic effects.

Conclusion: Our findings offer a new approach for the treatment of drug-resistant bacteria by potentiating inhibitory effects of existing antibiotics, and delivering them using a nontoxic formulation.

Keywords: ampicillin, rosette nanotubes, gold nanoparticles, S. aureus, methicillin-resistant S. aureus

\section{Introduction}

Resistance to $\beta$-lactam antibiotics appeared alongside the first use of penicillin in the 1940s. Bacteria strains, such as Staphylococcus aureus (S. aureus), rapidly evolved to produce enzymes that deactivate the antibiotic. Shortly after, the penicillin derivative methicillin was introduced due to its proved resistance to bacterial enzymes. However, resistance to methicillin developed with the growth of a bacterial isolate of $S$. aureus called methicillin-resistant $S$. aureus (MRSA). ${ }^{1,2}$

Regardless of the influence of risk factors and country variability, the increasing prevalence of $S$. aureus and MRSA infections necessitates the need for new antibiotics and/or therapeutic formulations. For instance, the $\beta$-lactam antibiotic ampicillin, an extended spectrum penicillin, was developed to extend the antibacterial activity of 
penicillins. ${ }^{3}$ While ampicillin was once used to treat a number of bacterial infections with particularly high efficiency, its widespread use has also triggered the growth of drugresistant bacterial isolates. ${ }^{4,5}$ The recurring growth of bacterial isolates has consequently prompted research for new antibiotic treatments. With the emergence of nanoscience and nanotechnology in the field of drug delivery, several reports have found that the bactericidal efficacy of ampicillin can be improved when conjugated to gold nanoparticles (AuNPs). ${ }^{5-7}$

AuNPs are an ideal drug delivery vehicle due to their low-toxicity, biocompatibility, high chemical stability, and ease of synthesis. ${ }^{8,9}$ Furthermore, antibiotics could be conjugated to AuNPs in one simple step. ${ }^{10}$ Surface functionalization of AuNPs with antibiotics occurs because the drugs can coordinate to the surface of the AuNPs via their carboxylic acid, hydroxyl, thiol, or amine functional groups. ${ }^{11}$ The resulting functionalization imparts antibacterial properties to the AuNPs that consequently result in bacteria degradation and death. ${ }^{12}$

In an effort to improve the efficacy and biocompatibility of antibiotic-conjugated AuNPs, our group has been concerned with the use of ultra-small AuNPs (ie, high surface area) grown on the surface of a new class of self-assembled nanotubes, rosette nanotubes (RNTs). RNTs are obtained through the self-assembly of a synthetic DNA base analog, the $\mathrm{G} \wedge \mathrm{C}$ motif. ${ }^{13-16}$ Intermolecular hydrogen bonding allows six $\mathrm{G} \wedge \mathrm{C}$ bases to form a supermacrocycle (rosette) maintained by 18 hydrogen bonds, which then self-organize to produce a tubular stack with tunable dimensions and surface chemistry (Figure 1). ${ }^{17}$

We have previously shown the nucleation, growth, and morphogenesis of nearly monodisperse AuNPs $(1.4 \mathrm{~nm} \pm 0.2 \mathrm{~nm})^{17}$ on self-assembled RNTs using a onepot reaction process. We have also developed a new synthetic strategy to prepare PEGylated RNTs (Figure 1) using $\mathrm{G} \wedge \mathrm{C}$ motifs covalently grafted with polyethylene glycol (PEG). PEGylated biomaterials have been shown in different studies to possess advantages for drug delivery, including reduced immunogenicity, improved pharmacokinetics, biodistribution, and biocompatibility. ${ }^{18-20}$ In addition, the RNTs were previously shown to be non-toxic ${ }^{21-23}$ and biocompatible with bone, ${ }^{24-32}$ cartilage, ${ }^{33,34}$ heart, ${ }^{35}$ skin, ${ }^{36}$ endothelial, ${ }^{37}$ and nerve cells functions. ${ }^{38}$

Based on these studies, here we present the preparation of a new nanocomposite material of ampicillin-conjugated AuNPs nucleated on PEGylated RNTs (Amp-AuNPs-PEG-RNT) and

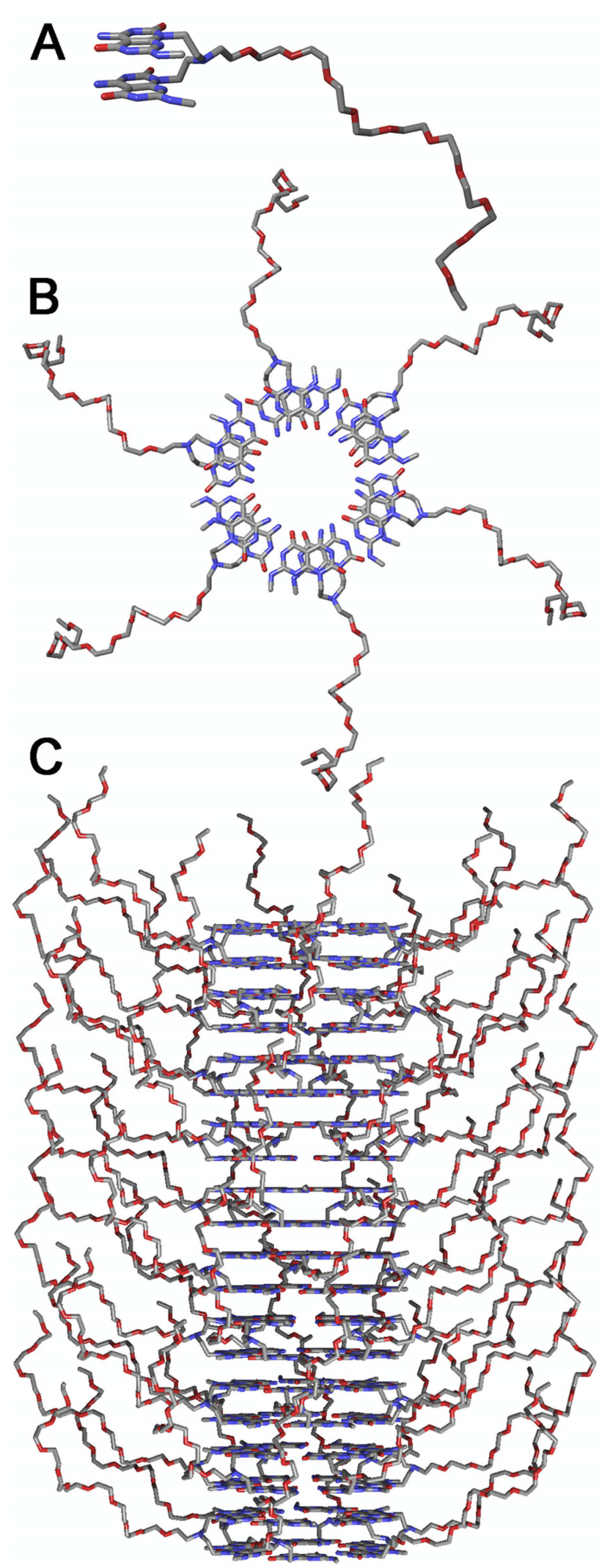

Figure I PEG-functionalized $\mathrm{G} \wedge \mathrm{C}$ base (A) self assembles into a rosette (B), which in turn self-assembles into a PEG-RNT via stacking interactions (C). Abbreviations: RNT, rosette nanotube; PEG, polyethylene glycol. 
an evaluation of its antibacterial properties against $S$. aureus and MRSA. Finally, we tested the cytocompatibility of this nanomaterial against human dermal fibroblasts (HDF) in vitro.

\section{Materials and methods}

\section{Synthesis of AuNPs on PEGylated RNTs}

The formation of AuNPs on PEGylated RNTs was studied in a systematic fashion by altering the ratios of reactants used (Table 1). The PEGylated RNTs used in the synthesis method were prepared using a strategy previously developed by the authors. ${ }^{13-17}$ A solution of PEGylated RNTs was treated with potassium tetrachloroaurate $\left(\mathrm{KAuCl}_{4}\right.$, Sigma) solution. The resulting solution was aged in the dark at room temperature for $24 \mathrm{hrs}$ then treated with hydrazine hydrate (Acros Organics). The final solution was stored in the dark at room temperature for an additional 4 days.

\section{Synthesis of ampicillin-conjugated AuNPs on PEGylated RNTs}

Amp-AuNPs-PEG-RNT nanocomposite was prepared using a one-pot reaction. Ampicillin solution (Fisher, 4 $\mu \mathrm{L}, 1 \% \mathrm{w} / \mathrm{w})$ was added to a solution of prepared AuNPs-PEG-RNTs (1 mL, Au-PEG-RNT-2, 2 days aging). The mixture was then aged in the dark at room temperature for 4 days. All the concentrations noted refer to the total ampicillin concentration in solution.

\section{Electron microscopy}

Transmission electron microscopy (TEM) and scanning electron microscopy (SEM) were used to image the formation of AuNPs on the RNTs. Samples were prepared according to our previously reported protocol. Briefly, carbon-coated 300-mesh copper grids (CF300-Cu from EM Sciences) were floated on droplets of AuNP solutions. After $1 \mathrm{~min}$, the grids were blotted with filter paper and air-dried for $24 \mathrm{hrs}$. TEM images were recorded on JEOL JEM-1010 instrument at $80 \mathrm{kV}$ and SEM images were recorded on a Hitachi $\mathrm{S} 4800$ at $3 \mathrm{kV}$ with $c a .3 \mathrm{~mm}$ working distance.

\section{Bacterial assays}

The bacterial growth curve is a typical method for quantifying the number of bacteria in a sample over a period of time. As the OD of bacterial solution increases with bacteria multiplication, a growth curve is obtained. In this study, OD values were continuously recorded at $600 \mathrm{~nm}$ on SpectraMax Paradigm (Molecular Devices, Sunnyvale, CA) for up to $24 \mathrm{hrs}$ at $37^{\circ} \mathrm{C}$.

Bacteria colonies of $S$. aureus (Staphylococcus aureus subsp. aureus, ATCC ${ }^{\circledR} 12600^{\mathrm{TM}}$ ) and MRSA (Staphylococcus aureus subsp. aureus, ATCC ${ }^{\circledR} 43300^{\mathrm{TM}}$ ) were suspended in tryptic soy broth (TSB, $30 \mathrm{~g} / \mathrm{L}, 5 \mathrm{~mL}$ ) and solutions were propagated for $16 \mathrm{hrs}$ in a shaking incubator at $37^{\circ} \mathrm{C}$. The solutions were diluted with TSB to a concentration of $10^{9}$ bacteria $/ \mathrm{mL}$, where the bacterial density was determined by measuring OD values at $600 \mathrm{~nm}$. Further dilution with TSB was made until a final concentration of $10^{6}$ bacteria/ $\mathrm{mL}$ was achieved. The resulting bacterial solution was then transferred into a 96-well plate with a volume of $100 \mu \mathrm{L}$ per well. The bacteria were then treated with Amp-AuNPs-PEGRNT (10 $\mu \mathrm{L}$, various concentrations). The final concentrations of ampicillin were $1.2,0.86,0.58,0.29,0.23$, and $0.12 \mu \mathrm{g} / \mathrm{mL}$. Negative control wells received $10 \mu \mathrm{L}$ of TSB only. For the treatment of MRSA, the final concentration of ampicillin in each well was $4,3.2,2 \mu \mathrm{g} / \mathrm{mL}, 1$, and $0.8 \mu \mathrm{g} / \mathrm{mL}$.

\section{HDF viability assay}

HDF (Lonza, CC-2509) were cultured in filter-sterilized (0.22 $\mu \mathrm{m}$, Corning) DMEM (Corning 10013CV) supplemented with 10\% FBS (ATCC SCRR-30-2020TM) and 1\% penicillin-streptomycin (P/S, Sigma-Aldrich) under standard culturing condition $\left(37^{\circ} \mathrm{C}\right.$, humidified, $5 \% \mathrm{CO}_{2} / 95 \%$ air). Cells at passage number of 4-6 were used in the experiments. To determine cell viability, HDF cells were seeded in a 96well plate at a density of 20,000 cells per $\mathrm{cm}^{2}$ and subsequently dosed with $10 \mu \mathrm{L}$ Amp-AuNPs-PEG-RNT (10 $\mu \mathrm{L}$,

Table I Concentration of PEG-RNTs, KAuCl,$\left(\mathrm{NH}_{2}\right)_{2}-\mathrm{H}_{2} \mathrm{O}$, and the ratios of PEG-RNTs/KAuCl $4 /\left(\mathrm{NH}_{2}\right)_{2}-\mathrm{H}_{2} \mathrm{O}$ used for gold deposition studies

\begin{tabular}{|c|c|c|c|}
\hline Sample & PEG-RNTs & $\mathrm{KAuCl}_{4}$ Solution & $\left(\mathrm{NH}_{2}\right)_{2}, \mathrm{H}_{2} \mathrm{O}$ \\
\hline Au-PEG-RNT-I & I mg/mL, $930 \mu \mathrm{M}, \mathrm{I} \mathrm{mL}$ & $3.77 \mathrm{mg} / \mathrm{mL}, 10 \mathrm{mM}, 9.3 \mu \mathrm{L}$, I eq & $32.1 \mu \mathrm{g} / \mathrm{mL}, \mathrm{I} \mathrm{mM}, 9.3 \mu \mathrm{L}, 0.1$ eq \\
\hline Au-PEG-RNT-2 & I mg/mL, $930 \mu \mathrm{M}, \mathrm{I} \mathrm{mL}$ & $3.77 \mathrm{mg} / \mathrm{mL}, 10 \mathrm{mM}, 18.6 \mu \mathrm{L}, 2 \mathrm{eq}$ & $32.1 \mu \mathrm{g} / \mathrm{mL}, \mathrm{I} \mathrm{mM}, 18.6 \mu \mathrm{L}, 0.2 \mathrm{eq}$ \\
\hline Au-PEG-RNT-3 & I mg/mL, $930 \mu \mathrm{M}, \mathrm{I} \mathrm{mL}$ & $3.77 \mathrm{mg} / \mathrm{mL}, 10 \mathrm{mM}, 37.2 \mu \mathrm{L}, 4$ eq & $32.1 \mu \mathrm{g} / \mathrm{mL}, \mathrm{I} \mathrm{mM}, 37.2 \mu \mathrm{L}, 4$ eq \\
\hline Au-PEG-RNT-4 & I mg/mL, $930 \mu \mathrm{M}, \mathrm{I} \mathrm{mL}$ & $3.77 \mathrm{mg} / \mathrm{mL}, 10 \mathrm{mM}, 74.4 \mu \mathrm{L}, 8 \mathrm{eq}$ & $32.1 \mu \mathrm{g} / \mathrm{mL}, \mathrm{I} \mathrm{mM}, 74.4 \mu \mathrm{L}, 8 \mathrm{eq}$ \\
\hline
\end{tabular}


various concentrations) in $100 \mu \mathrm{L}$ DMEM. The final concentrations of ampicillin were $0.8,1,2,3.2$, and $4 \mu \mathrm{g} / \mathrm{mL}$. The cells were incubated under standard culturing conditions for 24 hrs. Negative control group contained DMEM only.

\section{MTS assay}

Antibacterial drugs and 20,000 cells $/ \mathrm{cm}^{2}$ were seeded in 96-well plates with a final volume of $100 \mu \mathrm{L} / w e l l$. An additional set of wells was added (medium only) for background subtraction. The mixtures were incubated for 24 hrs, after which the solutions were gently removed from the wells. To each well, $20 \mu \mathrm{L}$ MTS ((3-(4,5-dimethylthiazol- 2-yl)-5-(3-carboxymethoxyphenyl)-2-(4-sulfophenyl)$2 \mathrm{H}$-tetrazolium), Promega medicine) solution and $100 \mu \mathrm{L}$ DMEM were added and the resulting solutions were incubated for $3 \mathrm{hrs}$ under standard cell culture condition $\left(37^{\circ} \mathrm{C}\right.$, humidified, $5 \% \mathrm{CO}_{2} / 95 \%$ air). The OD values at $490 \mathrm{~nm}$ against background were then recorded.

Minimum inhibitory concentration (MIC) values were determined using Prism 7 (GraphPad software) to fit concentration data based on a modified Gompertz function. ${ }^{39}$ All cell and bacterial experiments were run in triplicate and repeated at least three times. One-tailed Student's $t$ tests were used to estimate the significant differences, with a $p$-value $\leq 0.05$.

\section{Results}

\section{Amp-AuNPs-PEG RNT nanocomposites}

TEM imaging was used to assess the nucleation and size of AuNPs on PEGylated RNTs (Figure 2). The presence of the RNTs is an indication that they did not disassemble under the conditions tested. It is apparent from the images that at high $\mathrm{KAuCl}_{4} / \mathrm{PEG}-\mathrm{RNTs}$ ratios, small and nearly monodisperse AuNPs were obtained. Statistical analysis of the particle diameter revealed an average diameter of 1.43 $\pm 0.5 \mathrm{~nm}$. However, at low concentration of $\mathrm{KAuCl}_{4}$ relative to PEG-RNTs (eg, 1:1 and 2:1), larger polydisperse AuNPs were observed (Figure S1).

Typically, conjugation of antibiotics with AuNPs requires chemical functionalization of the AuNPs. ${ }^{40}$ However, these subsequent steps could affect the efficacy of the antibiotics. ${ }^{41,42}$ In this study, we used a one-pot synthesis method to conjugate ampicillin to AuNPs on PEG-RNTs without further modification of the surface of the AuNPs or the antibiotic.

An earlier report by Brown et al showed that ampicillin can be conjugated to AuNPs via the thioether moiety on ampicillin. ${ }^{5}$ We anticipate a similar type of coordination in this study as depicted in Figure 3. As a result, the TEM images of Amp-AuNPs-PEG-RNTs show that the average diameter of the AuNPs increased to $1.86 \pm 0.32 \mathrm{~nm}$ suggesting that ampicillin is effectively coordinated to the surface of the AuNPs.

\section{Bacterial inhibition}

The antibacterial activity of ampicillin conjugated to AuNPs on PEG-RNTs was compared to ampicillin alone against $S$. aureus (Figures $\mathrm{S} 2$ and $\underline{\mathrm{S} 3}$ ). The results showed that bacteria growth treated with Amp-AuNPs-PEG-RNT at concentrations higher than $0.58 \mu \mathrm{g} / \mathrm{mL}$ was inhibited for $24 \mathrm{hrs}$ (MIC $=0.58 \mu \mathrm{g} / \mathrm{mL}$, Figure 4). The free ampicillin solutions were less effective at inhibiting bacteria growth than AmpAuNPs-PEG-RNT (MIC=0.71 $\mu \mathrm{g} / \mathrm{mL})$ (Figure S2).
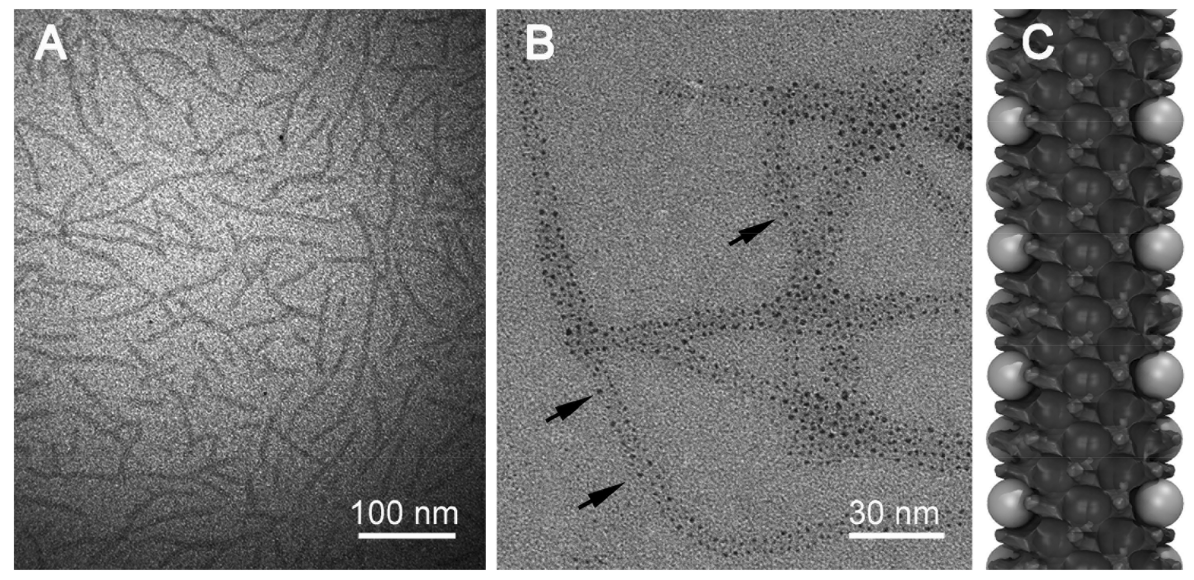

Figure 2 TEM images of (A) PEG-RNTs, (B) AuNP/PEG-RNT nanocomposite and (C) model of the nanocomposite. Black arrows in (B) point at AuNPs grown on PEGRNT surface.

Abbreviations: RNT, rosette nanotube; PEG, polyethylene glycol; TEM, transmission electron microscopy; AuNP, gold nanoparticle. 


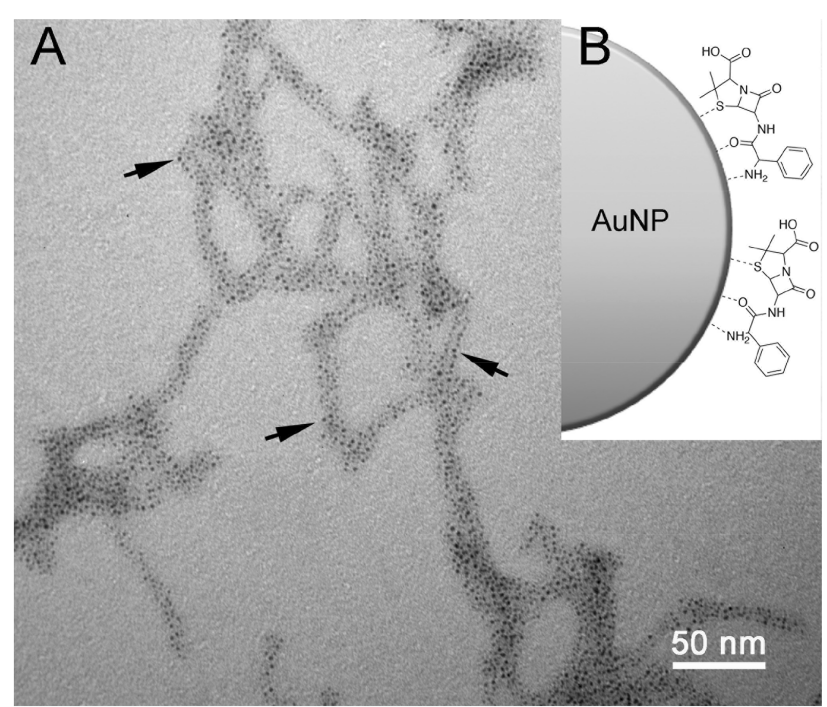

Figure 3 TEM image AuNPs-PEG-RNT functionalized with ampicillin (A), and schematic representation of ampicillin coordination to AuNPs (B). Black arrows point at AuNPs on PEG-RNT surface.

Abbreviations: RNT, rosette nanotube; PEG, polyethylene glycol; TEM, transmission electron microscopy; AuNPs, gold nanoparticles.

The antibacterial activity of Amp-AuNPs-PEG-RNT was also evaluated against MRSA. Unlike S. aureus, MRSA required a higher concentration of Amp-AuNPsPEG-RNT $(2-4 \mu \mathrm{g} / \mathrm{mL})$ to exert an antibacterial effect (Figure 5). This higher concentration is likely due to the acquired gene in MRSA (mecA) that encodes for the penicillin-binding protein PBP2a. ${ }^{43,44}$ In contrast, the MRSA grew rapidly when treated with ampicillin alone, suggesting that Amp-AuNPs-PEG-RNT is effective at delivering ampicillin.

Based on the results from Figure 5, the MIC value of Amp-AuNPs-PEG-RNT against MRSA was estimated to be $4 \mu \mathrm{g} / \mathrm{mL}$. Earlier reports have shown that ampicillin alone has MIC values ranging from 32 to $50 \mu \mathrm{g} / \mathrm{mL}$ against MRSA. ${ }^{45-47}$ Therefore, the MIC of the nanocomposite against MRSA in this study is at least ten times lower than ampicillin alone.

To test the cytocompatibility of Amp-AuNPs-PEG-RNT an MTS assay was carried out using HDF cells. The cells treated with $0-4 \mu \mathrm{g} / \mathrm{mL}$ of ampicillin ( $70 \mu \mathrm{g} / \mathrm{mL}$ of AuNPs) exhibited viability similar to control groups after $24 \mathrm{hrs}$ exposure (Figure 6).

\section{Discussion}

We have shown that the nanocomposite, Amp-AuNPs-PEGRNT, has greater antibacterial activity (18\% lower MIC) than the antibiotic ampicillin alone against $S$. aureus. While there are many MRSA strains, Staphylococcus aureus subsp. aureus, $\mathrm{ATCC}^{\circledR} 43300^{\mathrm{TM}}$ exhibits methicillin resistance and expresses mecA to produce PBP2a. ${ }^{48}$ Therefore, for this MRSA strain, the ampicillin-loaded nanocomposite was 10-20 times lower than ampicillin alone, suggesting significantly enhanced antibacterial properties. This could result from three possible mechanisms operating at the same time, with possible synergistic effects among the three: 1) electrostatic interaction between the cationic nanocomposite

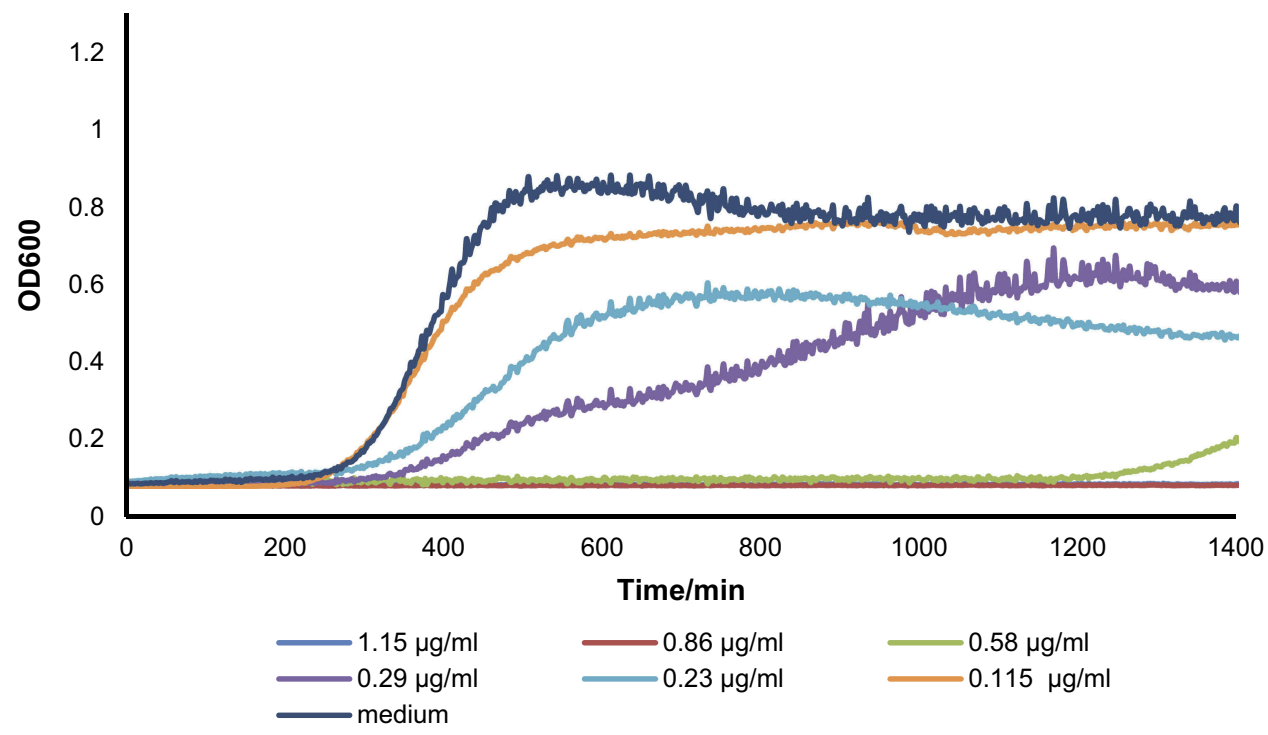

Figure 4 Bacterial growth inhibition curve for S. aureus up to 24 hrs against Amp-AuNPs-PEG-RNT with different ampicillin concentrations and medium-only (negative control). Values are mean $\pm S D, N=3$.

Abbreviations: RNT, rosette nanotube; PEG, polyethylene glycol; AuNPs, gold nanoparticles. 


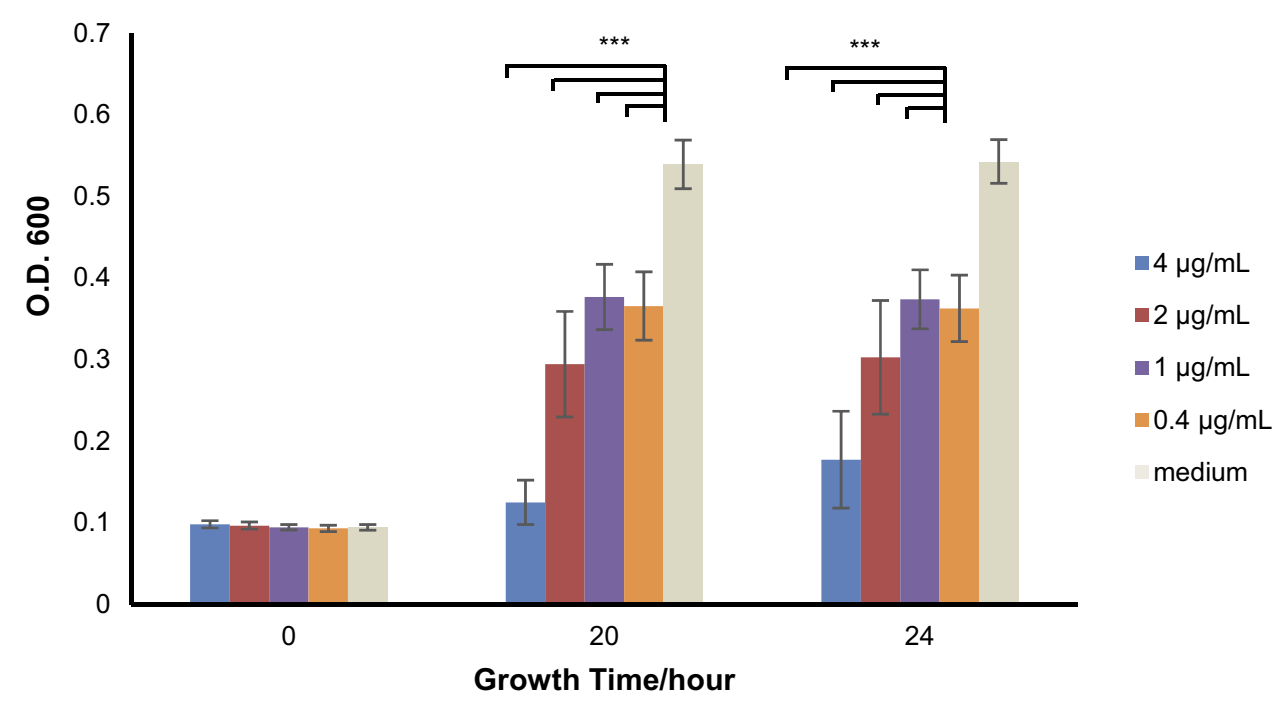

Figure 5 Bacterial growth inhibition graph for MRSA up to 24 hrs against Amp-AuNPs-PEG-RNT with different concentrations of ampicillin and medium-only (negative control). Values are mean $\pm S D, N=3, p^{* * *}<0.00$ I when compared to medium-only.

Abbreviations: MRSA, methicillin-resistant S. aureus; RNT, rosette nanotube; PEG, polyethylene glycol; AuNPs, gold nanoparticles.

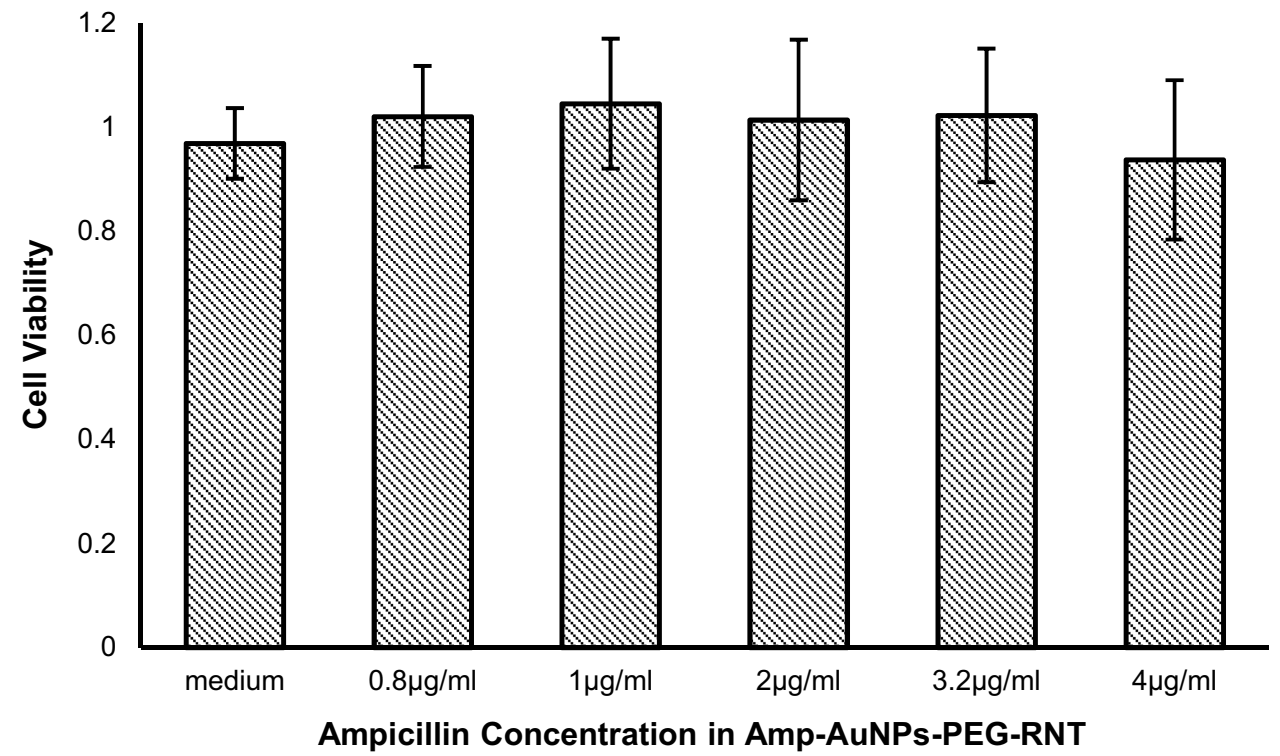

Figure $6 \mathrm{HDF}$ cell viability after I-day exposure to Amp-AuNPs-PEG-RNT with total ampicillin concentrations varying from 0 to $4 \mu \mathrm{g} / \mathrm{mL}$. Values are mean \pm SD, $\mathrm{N}=3$. Abbreviations: RNT, rosette nanotube; PEG, polyethylene glycol; AuNPs, gold nanoparticles; HDF, human dermal fibroblasts.

and negatively charged bacterial surface, 2) AuNP bacterial membrane disruption, and 3) ampicillin mode of action.

The cationic nature of the nanocomposite ${ }^{13-17}$ suggests a possible mechanism that could help deliver the antibiotic to the target bacteria. Previous authors have reported influences of cell-surface charge against different cationic antimicrobial agents. ${ }^{45,49,50}$ These studies have detected electrostatic attractions between the antimicrobial agents and negatively charged bacterial surfaces which consequently induce a binding effect. Therefore, the electrostatic attraction seems to play an important role in potentially binding the nanocomposite to the bacteria surface, which thereby increases the likelihood of delivery of the ampicillin.

In addition to the overall surface charge of the nanocomposite, the AuNPs of the nanocomposite could disrupt the bacterial membrane thereby contributing to bacteria death. For example, Cui et al have shown that AuNPs exert their therapeutic effects by interfering with bacterial metabolism, notably by collapsing the membrane 
potential, limiting ATP synthase activity and inhibiting tRNA binding to the ribosomes. ${ }^{51}$ These effects induced by the AuNPs offer a possible secondary mechanism for the enhanced antibiotic activity of the nanocomposite against the two strains of bacteria.

Finally, a third possible mechanism for the observed enhanced antibacterial activity is the mode of action of ampicillin. It is well understood that the $\beta$-lactam antibiotics, such as ampicillin, target penicillin-binding proteins required for bacterial peptidoglycan (the polymer of amino acids that make up the bacterial cell wall) synthesis, thereby resulting in bacterial lysis. ${ }^{52}$ Therefore, this mechanism may have been retained in the inhibition of the bacteria with the nanocomposite alongside the two mechanisms discussed above.

In another experiment, we tested the cytocompatibility in vitro of the nanocomposite against HDF cells using different concentrations of ampicillin. Under $4 \mu \mathrm{g} / \mathrm{mL}$ of ampicillin (equivalent to $70 \mu \mathrm{g} / \mathrm{mL}$ of AuNPs) and $24 \mathrm{hrs}$ exposure, HDF cells exhibited viability similar to control groups. Earlier reports suggest that charges on the surfaces of AuNPs are the primary factor contributing to their cytotoxicity at concentrations as low as $10 \mu \mathrm{g} / \mathrm{mL}$. Charged AuNPs decrease the membrane potential and intracellular $\mathrm{Ca}^{2+}$ levels, resulting in up- or downregulated gene expression, ${ }^{53}$ whereas neutral AuNPs do not. ${ }^{54,55}$ Our results show that our nanocomposite formulation containing $70 \mu \mathrm{g} / \mathrm{mL}$ of AuNPs was negligible confirming that the AuNPs are bound to the RNTs and may be released in a controlled manner.

\section{Conclusion}

We have presented the formation of a new nanocomposite composed of ampicillin-conjugated AuNPs on the surface of PEGylated RNTs to inhibit the bacterial growth of $S$. aureus and MRSA. The nanocomposite displayed significantly higher antibacterial activity against $S$. aureus than ampicillin alone. At higher concentration of AuNPs, we have also shown that the nanocomposite inhibits MRSA growth. Taken together, these results establish the enhanced potential of antibiotics such as ampicillin when combined with the AuNPs-PEG-RNTs and lay a foundation for future research of this biomaterial against antibiotic-resistant bacteria.

\section{Acknowledgments}

This research was funded by the Department of Chemical Engineering, Northeastern University. The authors would also like to thank Dr Thomas J. Webster for providing the facilities for this project.

\section{Disclosure}

The authors report no conflicts of interest in this work.

\section{References}

1. Lim D, Strynadka NC. Structural basis for the beta lactam resistance of PBP2a from methicillin-resistant Staphylococcus aureus. Nat Struct Biol. 2002;9(11):870-876. doi:10.1038/nsb858

2. Davies J, Davies D. Origins and evolution of antibiotic resistance. Microbiol Mol Biol Rev. 2010;74(3):417-433. doi:10.1128/ MMBR.00016-10

3. Kaushik D, Mohan M, Borade DM, Swami OC. Ampicillin: rise fall and resurgence. J Clin Diagn Res. 2014;8(5):ME01. doi:10.7860/ JCDR/2014/6788.3956

4. Zhao YJ, Jiang X. Multiple strategies to activate gold nanoparticles as antibiotics. Nanoscale. 2013;5:8340-8350. doi:10.1039/c3nr01990j

5. Brown AN, Smith K, Samuels TA, Lu J, Obare SO, Scott ME. Nanoparticles functionalized with ampicillin destroy multiple-antibiotic-resistant isolates of Pseudomonas aeruginosa and Enterobacter aerogenes and methicillin-resistant Staphylococcus aureus. Appl Environ Microbiol. 2012;78(8):2768-2774. doi:10.1128/ AEM.06513-11

6. Saha B, Bhattacharya J, Mukherjee A, et al. In vitro structural and functional evaluation of gold nanoparticles conjugated antibiotics. Nano Res Lett. 2007;2(12):614. doi:10.1007/s11671-007-9104-2

7. Zhao Y, Tian Y, Cui Y, Liu W, Ma W, Jiang X. Small moleculecapped gold nanoparticles as potent antibacterial agents that target gram-negative bacteria. J Am Chem Soc. 2010;132(35):12349-12356. doi:10.1021/ja1028843

8. Bar-Ilan O, Albrecht RM, Fako VE, Furgeson DY. Toxicity assessments of multisized gold and silver nanoparticles in zebrafish embryos. Small. 2009;5(16):1897-1910. doi:10.1002/smll.200801716

9. Shamaila S, Zafar N, Riaz S, Sharif R, Nazir J, Naseem S. Gold nanoparticles: an efficient antimicrobial agent against enteric bacterial human pathogen. Nanomaterials. 2016;6(4):71. doi:10.3390/ nano6040071

10. Yang X, Yang M, Pang B, Vara M, Xia Y. Gold nanomaterials at work in biomedicine. Chem Rev. 2015;115(19):10410-10488. doi:10.1021/acs.chemrev.5b00193

11. Song YZ, Zhu AF, Song Y, Cheng ZP, Xu J, Zhou JF. Experimental and theoretical study on the synthesis of gold nanoparticles using ceftriaxone as a stabilizing reagent for and its catalysis for dopamine. Gold Bull. 2012;45(3):153-160. doi:10.1007/s13404-012-0059-4

12. Li X, Robinson SM, Gupta A, et al. Functional gold nanoparticles as potent antimicrobial agents against multi-drug-resistant bacteria. ACS Nano. 2014;8(10):10682-10686. doi:10.1021/nn5042625

13. Fenniri H, Mathivanan P, Vidale KL, et al. Helical rosette nanotubes: design, self-assembly, and characterization. $J$ Am Chem Soc. 2001;123(16):3854-3855. doi:10.1021/ja0058861

14. Beingessner RL, Deng BL, Fanwick PE, Fenniri H. A Regioselective Approach to Trisubstituted 2 (or 6)-Arylaminopyrimidine-5-carbaldehydes and Their Application in the Synthesis of Structurally and Electronically Unique G/C Base Precursors. J Org Chem. 2008;73 (3):931-939. doi:10.1021/jo7021422

15. Beingessner RL, Fan Y, Fenniri H. Molecular and supramolecular chemistry of rosette nanotubes. RSC Adv. 2016;6(79):75820-75838. doi:10.1039/C6RA16315G

16. Moralez JG, Raez J, Yamazaki T, Motkuri RK, Kovalenko A, Fenniri H. Helical rosette nanotubes with tunable stability and hierarchy. $J$ Am Chem Soc. 2005;127(23):8307-8309. doi:10.1021/ja051496t

17. Chhabra R, Moralez JG, Raez J, et al. One-pot nucleation, growth, morphogenesis, and passivation of $1.4 \mathrm{~nm} \mathrm{Au}$ nanoparticles on selfassembled rosette nanotubes. J Am Chem Soc. 2009;132(1):32-33. doi:10.1021/ja908775g 
18. Roberts M, Bentley M, Harris J. Chemistry for peptide and protein PEGylation. Adv Drug Deliv Rev. 2012;64:116-127. doi:10.1016/j. addr.2012.09.025

19. Pelaz B, Del Pino P, Maffre P, et al. Surface functionalization of nanoparticles with polyethylene glycol: effects on protein adsorption and cellular uptake. ACS Nano. 2015;9(7):6996-7008. doi:10.1021/ acsnano. 5 b01326

20. Kooijmans S, Fliervoet L, Van Der Meel R, et al. PEGylated and targeted extracellular vesicles display enhanced cell specificity and circulation time. J Control Release. 2016;224:77-85. doi:10.1016/j. jconrel.2016.01.009

21. Journeay WS, Singh SS, Moralez JG, Fenniri H, Singh B. Macrophage Inflammatory Response to Self-Assembling Rosette Nanotubes. Small. 2009;5:1446-1452. doi:10.1002/smll.200801717

22. Journeay WS, Singh SS, Moralez JG, Fenniri H, Singh B. Novel Rosette Nanotubes Show Low Acute Pulmonary Toxicity In Vivo. Int J Nanomed. 2008;3:373-383.

23. Journeay WS, Singh SS, Moralez JG, Fenniri H, Singh B. Low inflammatory activation by self-assembling Rosette nanotubes in human Calu-3 pulmonary epithelial cells. Small. 2008;4:817-823. doi:10.1002/smll.200700700

24. Sun L, Zhang L, UD H, Fenniri H, Webster TJ. Bioactive Rosette Nanotube-Hydroxyapatite Nanocomposites Improve Osteoblast Functions. Tissue Eng A. 2012;1741-1750. doi:10.1089/ten. tea. 2011.0456

25. Zhang L, Hemraz UD, Fenniri H, Webster TJ. Tuning cell adhesion on titanium with osteogenic rosette nanotubes. $J$ Biomed Mater Res Part A. 2010;95A:550-563. doi:10.1002/jbm.a.v95a:2

26. Zhang L, Rodriguez R, Raez J, Fenniri H, Webster TJ. Biologically Inspired Rosette Nanotubes and Nanocrystalline Hydroxyapatite Hydrogel Nanocomposites as Improved Bone Substitutes. Nanotechnology. 2009;20:175101/1-175101/12.

27. Zhang L, Rakotondradany F, Myles AJ, Fenniri H, Webster TJ. Arginine-glycine-aspartic acid modified rosette nanotube-hydrogel composites for bone tissue engineering. Biomaterials. 2009;30:1309-1320. doi:10.1016/j.biomaterials.2008.11.020

28. Zhang L, Chen Y, Rodriguez J, Fenniri H, Webster TJ. Biomimetic Helical Rosette Nanotubes and Nanocrystalline Hydroxyapatite Coatings on Titanium for Improving Orthopedic Implants. Int $J$ Nanomed. 2008;3:323-333.

29. Zhang L, Ramsaywack S, Webster TJ. Enhanced osteoblast adhesion on self-assembled nanostructured hydrogel scaffolds. Tissue Eng Part A. 2008;4:1353-1364. doi:10.1089/ten.tea.2006.0436

30. Chun AL, Webster TJ, Fenniri H. Helical rosette nanotubes: topographical and chemical roles in osteoblast attachment. $A d v S c i$ Technol. 2006;53:1-8. doi:10.4028/www.scientific.net/AST.53

31. Chun AL, Moralez JG, Webster TJ, Fenniri H. Helical rosette nanotubes: a biomimetic coating for orthopedics? Biomaterials. 2005;26:7304-7309. doi:10.1016/j.biomaterials.2005.05.080

32. Chun A, Moralez JG, Fenniri H, Webster TJ. Helical rosette nanotubes: a more effective orthopaedic implant material. Nanotechnology. 2004;15:234-239. doi:10.1088/0957-4484/15/4/022

33. Childs A, Hemraz UD, Castro NJ, Fenniri H, Zhang LG. Novel biologically-inspired rosette nanotube PLLA scaffolds for improving human mesenchymal stem cell chondrogenic differentiation. Biomed Mater. 2013;8:065003. doi:10.1088/1748-6041/8/6/065003

34. Chen Y, Pareta RA, Bilgen B, et al. Self-assembled rosette nanotube/ hydrogel composites for cartilage tissue engineering. Tissue Eng Part C. 2010;16:1233-1243. doi:10.1089/ten.tec.2009.0400

35. Meng X, Stout DA, Sun L, Beingessner RL, Fenniri H, Webster TJ. Novel injectable biomimetic hydrogels with carbon nanofibers and self assembled rosette nanotubes for myocardial applications. $J$ Biomed Mater Res Part A. 2012;101A:1095-1102. doi:10.1002/jbm. a.v101a.4
36. Sun L, Li D, Hemraz UD, Fenniri H, Webster TJ. Self-assembled twin base linker and poly(2-hydroxyethyl methacrylate) hydrogels promote skin cell functions. J Biomed Mater Res Part A. 2013. doi:10.1002/jbma. 35008

37. Fine E, Zhang L, Fenniri H, Webster TJ. B Enhanced Endothelial Cell Functions on Helical Rosette Nanotubes Coated Titanium Vascular Stents. Int J Nanomed. 2009;4:91-97.

38. Puzan ML, Legesse B, Koppes RA, Fenniri H, Koppes AN. Bioactive Organic Rosette Nanotubes Support Sensory Neurite Outgrowth. ACS Biomat Sci Eng. 2018;4:1630-1640.

39. Lambert R, Pearson J. Susceptibility testing: accurate and reproducible minimum inhibitory concentration (MIC) and non-inhibitory concentration (NIC) values. J Appl Microbiol. 2000;88(5):784-790.

40. Ray S, Das AK, Banerjee A, Smart oligopeptide gels: in situ formation and stabilization of gold and silver nanoparticles within supramolecular organogel networks. Chem Commun. 2006;(26):28162818. doi:10.1039/b605498f

41. Droste JC, Jeraj HA, MacDonald A, Farrington K. Stability and in vitro efficacy of antibiotic-heparin lock solutions potentially useful for treatment of central venous catheter-related sepsis. J Antimicrob Chemother. 2003;51(4):849-855. doi:10.1093/jac/dkg179

42. Bhattacharya D, Saha B, Mukherjee A, Santra CR, Karmakar P. Gold nanoparticles conjugated antibiotics: stability and functional evaluation. Nanosci Nanotechnol. 2012;2(2):14-21. doi:10.5923/j.nn.20 120202.04

43. Pinho MG, Filipe SR, de Lencastre H, Tomasz A. Complementation of the essential peptidoglycan transpeptidase function of penicillinbinding protein 2 (PBP2) by the drug resistance protein PBP2A in Staphylococcus aureus. J Bacteriol. 2001;183(22):6525-6531. doi:10.1128/JB.183.22.6525-6531.2001

44. Wang Y, Yan W, Fu S, et al. Multiple cross displacement amplification coupled with nanoparticles-based lateral flow biosensor for detection of staphylococcus aureus and identification of methicillinresistant S. aureus. Front Microbiol. 2018;9:907. doi:10.3389/ fmicb.2018.00907

45. Foxley MA, Friedline AW, Jensen JM, et al. Efficacy of ampicillin against methicillin-resistant Staphylococcus aureus restored through synergy with branched poly(ethylenimine). J Antibiot. 2016;69 (12):871. doi:10.1038/ja.2016.44

46. Santiago C, Pang EL, Lim K-H, Loh H-S, Ting KN. Reversal of ampicillin resistance in MRSA via inhibition of penicillin-binding protein 2a by Acalypha wilkesiana. Biome Res Int. 2014;2014:1-7. doi:10.1155/2014/965348

47. Konaté K, Mavoungou JF, Lepengué AN, et al. Antibacterial activity against $\beta$-lactamase producing Methicillin and Ampicillin-resistants Staphylococcus aureus: fractional Inhibitory Concentration Index (FICI) determination. Ann Clin Microbiol Antimicrob. 2012;11 (1):18. doi:10.1186/1476-0711-11-18

48. Ubukata K, Nonoguchi R, Matsuhashi M, Konno M. Expression and inducibility in Staphylococcus aureus of the mecA gene, which encodes a methicillin-resistant S. aureus-specific penicillin-binding protein. J Bacteriol. 1989;171(5):2882-2885. doi:10.1128/jb.171.5. 2882-2885.1989

49. Rawlinson L-AB, O'Gara JP, Jones DS, Brayden DJ. Resistance of Staphylococcus aureus to the cationic antimicrobial agent poly (2(dimethylamino ethyl) methacrylate)(pDMAEMA) is influenced by cell-surface charge and hydrophobicity. J Med Microbiol. 2011;60 (7):968-976. doi:10.1099/jmm.0.025619-0

50. Wang X, Cui Q, Yao C, et al. Conjugated polyelectrolyte-silver nanostructure pair for detection and killing of bacteria. Adv Mat Technol. 2017;2(7):1700033. doi:10.1002/admt.201700033

51. Cui Y, Zhao Y, Tian Y, Zhang W, Lü X, Jiang X. The molecular mechanism of action of bactericidal gold nanoparticles on Escherichia coli. Biomaterials. 2012;33(7):2327-2333. doi:10.1016/ j.biomaterials.2011.11.057 
52. Kapoor G, Saigal S, Elongavan A. Action and resistance mechanisms of antibiotics: A guide for clinicians. J Anaesthesiol Clin Pharmacol. 2017;33(3):300-305. doi:10.4103/joacp.JOACP_349_15

53. Goodman CM, McCusker CD, Yilmaz T, Rotello VM. Toxicity of gold nanoparticles functionalized with cationic and anionic side chains. Bioconjug Chem. 2004;15(4):897-900. doi:10.1021/bc049951i
54. Connor EE, Mwamuka J, Gole A, Murphy CJ, Wyatt MD. Gold nanoparticles are taken up by human cells but do not cause acute cytotoxicity. Small. 2005;1(3):325-327. doi:10.1002/smll.200400093

55. Schaeublin NM, Braydich-Stolle LK, Schrand AM, et al. Surface charge of gold nanoparticles mediates mechanism of toxicity. Nanoscale. 2011;3(2):410-420. doi:10.1039/c0nr00478b

\section{Publish your work in this journal}

The International Journal of Nanomedicine is an international, peerreviewed journal focusing on the application of nanotechnology in diagnostics, therapeutics, and drug delivery systems throughout the biomedical field. This journal is indexed on PubMed Central, MedLine, CAS, SciSearch ${ }^{\mathbb{B}}$, Current Contents ${ }^{\mathbb{B}} /$ Clinical Medicine, $^{2}$
Journal Citation Reports/Science Edition, EMBase, Scopus and the Elsevier Bibliographic databases. The manuscript management system is completely online and includes a very quick and fair peer-review system, which is all easy to use. Visit http://www.dovepress.com/ testimonials.php to read real quotes from published authors. 